\title{
PENGEMBANGAN MEDIA INTERAKTIF TEKNOLOGI MENJAHIT SEBAGAI SCAFFOLDING PENGUASAAN PENGETAHUAN KONSEPTUAL
}

\author{
Christiana Sukmawati ${ }^{1}$, Dewi Suliyanthini ${ }^{2}$, Shinta Doriza \\ Universitas Negeri Jakarta ${ }^{1},{ }^{2},{ }^{3}$ \\ sukmachristiana@gmail.com,dsuliyanthini@gmail.com, shintadoriza@unj.ac.id
}

\begin{abstract}
ABSTRAK
Penelitian ini bertujuan untuk mengembangkan media pembelajaran mata pelajaran teknologi menjahit bagi siswa kelas X Kompetensi Keahlian Tata Busana di Sekolah Menengah Kejuruan dengan kompetensi dasar menganalisis keselamatan dan kecelakaaan kerja. Metodologi penelitian ini menggunakan model R n D Borg and Gall yang dimodifikasi menjadi sembilan tahapan yang meliputi penelitian dan pengumpulan data, perencanaan pembuatan produk, pengembangan format produk awal, uji coba awal, revisi produk awal, uji coba lapangan, revisi produk hasil uji lapangan, uji pelaksanaan lapangan, dan revisi produk akhir. Hasil penelitian menunjukkan bahwa media pembelajaran interaktif dinilai layak untuk digunakan berdasarkan hasil persentase dari ahli materi sebesar $91.67 \%$ dan ahli media sebesar 90\%. Kelayakan media pembelajaran berdasarkan respon dari siswa juga dinyatakan layak dengan persentase $89 \%$ untuk uji coba pada kelompok kecil dan 87\% untuk uji coba pada kelompok besar. Efektivitas penggunaan media interaktif teknologi menjahit dinilai cukup baik, hal tersebut dapat dilihat dari kenaikan rata-rata hasil evaluasi berupa tes. Saat dilakukan pre test dan post tes di uji coba kelompok kecil mengalami peningkatan rata-rata nilai sebesar 17.5 dengan nilai rata-rata pre test 69.5 dan post test 87, sedangkan saat di uji coba di kelompok besar juga ada peningkatan nilai rata-rata yang cukup baik sebesar 14 dengan nilai rata-rata pre test 71 dan rata-rata post test 85 . Media interaktif teknologi menjahit dapat digunakan sebagai scaffolding penguasaan pengetahuan konseptual siswa.
\end{abstract}

Kata Kunci : Media Interaktif, Scaffolding, Menjahit

\section{PENDAHULUAN}

Media pembelajaran merupakan salah satu komponen yang memiliki peran penting dalam sebuah proses pembelajaran. Media pembelajaran juga merupakan komponen sumber belajar atau wahana fisik yang mengandung materi intruksional di lingkungan siswa yang dapat merangsang siswa untuk belajar ${ }^{1}$. Menurut teori Edgar Dale dalam ${ }^{2}$, pengalaman belajar seseorang $82 \%$ diperoleh melalui indra penglihat, $12 \%$ diperoleh dari indra pendengar, dan $6 \%$ diperoleh dari indra yang lain. Dari data tersebut, dapat diambil kesimpulan bahwa penyampaian materi pelajaran yang memanfaatkan indra penglihatan akan memperoleh hasil yang paling tinggi. Apabila

\footnotetext{
${ }^{1}$ Azhar Arsyad, Media Pembelajaran (Jakarta: PT. Raja Grafindo Persada, 2013).

${ }^{2}$ Arsyad.
}

Al Qalam: Jurnal Ilmiah Keagamaan dan Kemasyarakatan Vol. 16, No. 1 Januari - Juni 2022 
Christiana Sukmawati, Dewi Suliyanthini, Shinta Doriza : Pengembangan Media Interaktif Teknologi Menjahit Sebagai Scaffolding Penguasaan Pengetahuan Konseptual

digabungkan antara pemanfaatan indra penglihatan dan pendengaran, maka hasil maksimal akan didapatkan. Oleh karena itu, media pembelajaran yang dapat memadukan kedua panca indra diyakini dapat memberikan peran penting dalam menunjang efektivitas pembelajaran.

Media interaktif merupakan media pembelajaran yang bisa mengkombinasikan pemanfaatan kedua panca indra tersebut. Menurut Hofstetter dalam ${ }^{3}$, media interaktif adalah pemanfaatan komputer untuk membuat dan menggabungkan teks, grafik, audio, gambar bergerak (video dan animasi) dengan menggabungkan link dan tool yang memungkinkan pemakai melakukan navigasi, berinteraksi, berkreasi, dan berkomunikasi. Media pembelajaran interaktif memiliki kelebihan dibandingkan dengan media pembelajaran yang lain. Berdasarkan penelitian "Pedagogic Effectiveness of Print, Interactive Media, and Online Resources: A Case Study of IGNOU Jyotsna" yang bersumber dari International Journal of Instruction, menyimpulkan bahwa media interaktif lebih diunggulkan daripada modul cetak dan pembelajaran online karena konten pembelajaran yang dilakukan menggunakan media interaktif untuk belajar mandiri lebih efektif ${ }^{4}$. Selain hal tersebut, penelitian lain dengan judul "Media Learning: Innovating Classroom Education In A Malaysian University Interactive" yang dimuat dalam jurnal Turkish Online Journal of Educational Technology, juga menyimpulkan hasil yang serupa yaitu media interaktif berperan dalam meningkatkan prestasi belajar siswa dan membuat siswa menjadi lebih aktif dan termotivasi dalam mengikuti proses pembelajaran ${ }^{5}$.

Inovasi media interaktif menjadi kebutuhan yang mendesak untuk dikembangkan. Terutama inovasi untuk menghasilkan media interaktif untuk mendukung penguasaan pengetahuan konseptual dalam pembelajaran teknologi menjahit. Teknologi menjahit merupakan mata pelajaran produktif dasar yang diberikan kepada siswa kelas X Kompetensi Keahlian Tata Busana di Sekolah Menengah Kejuruan. Materi-materi pokok yang terdapat pada mata pelajaran teknologi menjahit tersebut sangat sulit dipahami oleh siswa jika diajarkan hanya menggunakan media konvensional karena setiap kompetensi dasar memiliki materi pokok dengan sub materi yang banyak. Berdasarkan hasil wawancara terbuka dengan 32 guru dan siswa Kompetensi Keahlian Tata Busana

\footnotetext{
${ }^{3}$ Benardo Periangan, Perancangan Media Interaktif Belajar Mengenal Angka Bagi Anak Prasekolah (Bandung: Universitas Komputer Indonesia, 2011).

${ }^{4}$ Jyotsna Dikshit, Suresh Garg, and Santosh Panda, 'Pedagogic Effectiveness of Print, Interactive Multimedia, and Online Resources: A Case Study of IGNOU', International Journal of Instruction, 6.1 (2013), 195-210 <https://doi.org/10.12973/iji.2016.9115a>.

5 Fui-Theng LEOW and Mai NEO, 'Interactive Multimedia Learning: Innovating Classroom Education in A Malaysian University', Turkish Online Journal of Educational Technology, 13.2 (2014), 99110.
}

Al Qalam: Jurnal Ilmiah Keagamaan dan Kemasyarakatan Vol. 16, No. 1 Januari - Juni 2022 
Christiana Sukmawati, Dewi Suliyanthini, Shinta Doriza : Pengembangan Media Interaktif Teknologi Menjahit Sebagai Scaffolding Penguasaan Pengetahuan Konseptual

di Sekolah Menengah Kejuruan menunjukkan bahwa 87,5\% guru dan siswa kesulitan mendapatkan media pembelajaran teknologi menjahit.

Pengetahuan konseptual merupakan dimensi pengetahuan yang mendasar dan sangat penting. Pengetahuan konseptual akan memudahkan siswa dalam mengembangkan dimensi pengetahuan pada level yang lebih tinggi, seperti level pengetahuan prosedural dan pengetahuan metakognitif. Penguasaan pengetahuan konseptual senantiasa harus ditekankan pada setiap pembelajaran agar siswa memiliki bekal dasar yang baik untuk mencapai kemampuan yang lain seperti penalaran, komunikasi, koneksi, dan pemecahan masalah ${ }^{6}$. Berdasarkan hasil observasi yang peneliti lakukan, penguasaan pengetahuan konseptual siswa pada mata pelajaran teknologi menjahit masih rendah. Hal itu dapat dilihat dari hasil ulangan harian pada kompetensi dasar menganalisis keselamatan dan kecelakaan kerja tahun pelajaran 2017-2018 yang rata-rata belum mencapai Kriteria Ketuntasan Minimal (KKM) yang di tetapkan sekolah. KKM yang ditetapkan untuk mata pelajaran teknologi menjahit adalah sebesar 75 yang harus dicapai oleh setiap siswa.

Oleh karena itu, untuk mendukung penguasaan pengetahuan konseptual, siswa dapat menggunakan alat bantu atau scaffolding. Dalam dunia pendidikan, scaffolding berarti bantuan yang diberikan pengajar kepada pembelajar dalam proses pembelajaran ${ }^{7}$. Sedangkan, pengertian scaffolding dalam pembelajaran adalah suatu kerangka pendukung untuk membangun suatu konstruksi ilmu pengetahuan ${ }^{8}$. Menurut Lajoie dalam ${ }^{9}$, scaffolding dapat berupa orang seperti tutor, dosen, orang tua, teman sebaya, alat, metode atau cara. Media interaktif merupakan alat atau media yang dapat guru gunakan sebagai scaffolding untuk mendukung penguasaan pengetahuan konseptual siswa.

Pada penelitian selanjutnya, peneliti tertarik untuk mengembangkan media interaktif pada mata pelajaran teknologi menjahit untuk siswa kelas X Kompetensi Keahlian Tata Busana di Sekolah Menengah Kejuruan sebagai scaffolding penguasaan pengetahuan konseptual. Kompetensi dasar yang akan dikembangkan yaitu menganalisis keselamatan dan kecelakaaan kerja. Peneliti

\footnotetext{
${ }^{6}$ Suhito, 'Menumbuhkan Kemampuan Kognitif Dimensi Konseptual Dalam Perkuliahan Geometri Pada Jurusan Matematika FMIPA Unnes', in Prisma, Prosiding Seminar Nasional Matematika, 2018, I, 464$70<$ https://journal.unnes.ac.id/sju/index.php/prisma/article/view/20133>.

7 Nur Wakhidah, 'Strategi Scaffolding Inspiring-Modeling-Writing-Reporting (IMWR) Dalam Menerapkan Pendekatan Saintifik Untuk Meningkatkan Keterampilan Proses Sains Dan Penguasaan Konsep' (Universitas Negeri Surabaya, 2016) <http://digilib.uinsby.ac.id/15748/>.

${ }^{8}$ Ese Monica Alake and Olatubosun Ogunseemi, 'Effects of Scaffolding Strategy on Learners ' Academic Achievement in Integrated Science at The Junior Secondary School Level', European Scientific Journal, 9.19 (2013), 149-55 <https://doi.org/http://dx.doi.org/10.19044/esj.2013.v9n19p\%25p>.

${ }^{9}$ Wakhidah.
}

Al Qalam: Jurnal Ilmiah Keagamaan dan Kemasyarakatan Vol. 16, No. 1 Januari - Juni 2022 
Christiana Sukmawati, Dewi Suliyanthini, Shinta Doriza : Pengembangan Media Interaktif Teknologi Menjahit Sebagai Scaffolding Penguasaan Pengetahuan Konseptual

tertarik untuk mengembangan media ini dikarenakan belum tersedianya media interaktif pada mata pelajaran teknologi menjahit. Penelitian ini mempunyai manfaat bagi guru-guru mata pelajaran teknologi menjahit, siswa kelas X Kompetensi Keahlian Tata Busana, dan Sekolah Menengah Kejuruan supaya lebih efektif dalam menyelenggarakan kegiatan pembelajaran untuk mencapai hasil pembelajaran yang maksimal.

\section{METODOLOGI PENELITIAN}

Dalam penelitian ini, model yang akan dikembangkan mengacu pada model pengembangan Research and Development $(R \& D)$ Borg dan Gall. Model pengembangan ini terdiri dari 10 tahapan yaitu penelitian dan pengumpulan data (research and information colleting), perencanaan (planning), pengembangan format produk awal (develop preliminary form of product), uji coba awal (preliminary field testing), revisi produk awal (main product revision), uji coba lapangan (main field testing), revisi produk hasil uji lapangan (operational product revision), uji pelaksanaan lapangan (operasional field testing), revisi produk akhir (final product revision), dan diseminasi dan implementasi (dissemination and implementation) ${ }^{10}$. Tahapan-tahapan pengembangan tersebut akan dibatasi oleh peneliti untuk disesuaikan dengan kebutuhan penelitian dan pengembangan yang dilakukan. Alasan pembatasan tersebut adalah keterbatasan waktu dan biaya yang dimiliki oleh peneliti. Hal tersebut juga berdasar dari pernyataan Borg dan Gall dalam ${ }^{11}$ yang menyatakan bahwa dalam penelitian tesis dan disertasi disarankan untuk membatasi penelitian dalam skala kecil, termasuk dimungkinkan membatasi tahapan penelitian. Tahapan penelitian dan pengembangan dalam penelitian ini dimodifikasi menjadi 9 tahapan yang meliputi penelitian dan pengumpulan data, perencanaan pembuatan produk, pengembangan format produk awal, uji coba awal, revisi produk awal, uji coba lapangan, revisi produk hasil uji lapangan, uji pelaksanaan lapangan, dan revisi produk akhir.

\section{HASIL DAN PEMBAHASAN}

Berdasarkan hasil wawancara terbuka terhadap 32 guru dan siswa di SMKN 3 Kota Tangerang, menyatakan bahwa $87,5 \%$ guru dan siswa kesulitan untuk mendapatkan media pembelajaran teknologi menjahit. Menurut guru mata pelajaran teknologi menjahit, sekolah tidak

\footnotetext{
2013).

${ }^{10}$ Endang Mulyatiningsih, Metode Penelitian Terapan Bidang Pendidikan (Bandung: Alfabeta,

${ }^{11}$ Emzir, Metodologi Penelitian Pendidikan Kuantitatif Dan Kualitataif (Bandung: Rajagrafindo Persada, 2012)
}

Al Qalam: Jurnal Ilmiah Keagamaan dan Kemasyarakatan Vol. 16, No. 1 Januari - Juni 2022 
Christiana Sukmawati, Dewi Suliyanthini, Shinta Doriza : Pengembangan Media Interaktif Teknologi Menjahit Sebagai Scaffolding Penguasaan Pengetahuan Konseptual

menyediakan media pembelajaran tersebut karena keterbatasan biaya. Oleh karena itu, pengembangan media pembelajaran interaktif menjadi kebutuhan yang medesak untuk dapat memenuhi kebutuhan guru dan siswa sehingga siswa dapat belajar mandiri tanpa memiliki ketergantungan yang tinggi terhadap guru.

Dari hasil menelaah beberapa jurnal dan buku, dapat disimpulkan bahwa media pembelajaran yang terbaik untuk digunakan guru saat kegiatan pembelajaran adalah media interaktif. Media pembelajaran media interaktif lebih diunggulkan daripada media pembelajaran lain seperti modul cetak dan pembelajaran online. Pengembangan media interaktif ini juga dapat dijadikan sebagai scaffolding untuk mendukung penguasaan pengetahuan konseptual siswa.

Setelah mengumpulkan data awal, langkah selanjutnya adalah melakukan perencanaan produk dengan cara mengumpulkan sumber belajar yang sesuai dengan mata pelajaran teknologi menjahit dengan materi menganalisis keselamatan dan kecelakaaan kerja. Sumber belajar diperoleh dari buku, modul, dan internet. Menentukan materi yang relevan dengan kompetensi dasar yang akan diteliti. Merancang desain untuk tampilan materi yang disesuaikan dengan karekteristik siswa di Sekolah Menengah Kejuruan. Menyiapkan bahan evaluasi berupa pre test dan post test serta menyiapkan angket untuk ahli materi dan ahli media. Tahap berikutnya adalah mengembangan format produk awal seperti pada gambar di bawah ini.

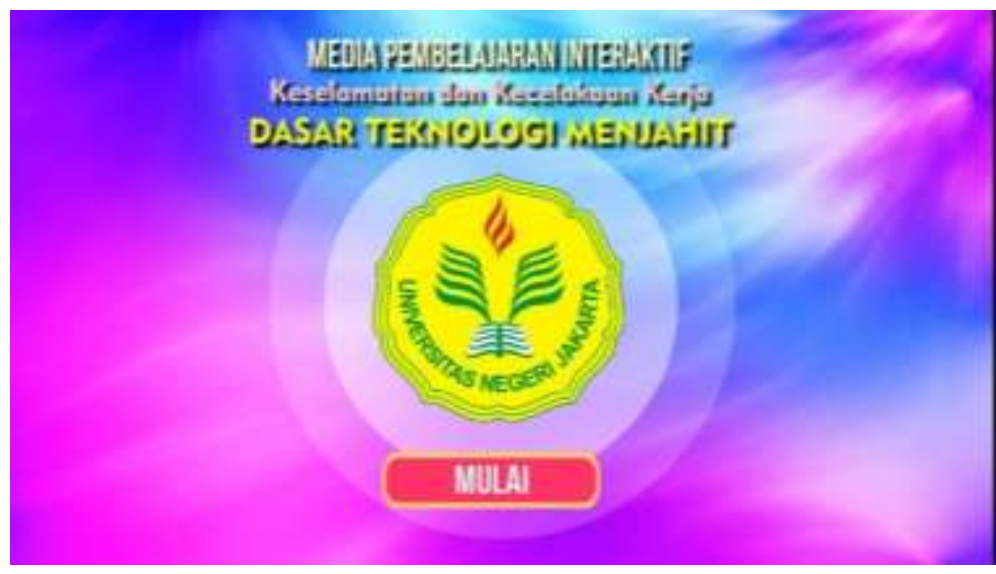

Gambar 1. Cover Media Pembelajaran Interaktif

Al Qalam: Jurnal Ilmiah Keagamaan dan Kemasyarakatan Vol. 16, No. 1 Januari - Juni 2022 
Christiana Sukmawati, Dewi Suliyanthini, Shinta Doriza : Pengembangan Media Interaktif Teknologi Menjahit Sebagai Scaffolding Penguasaan Pengetahuan Konseptual

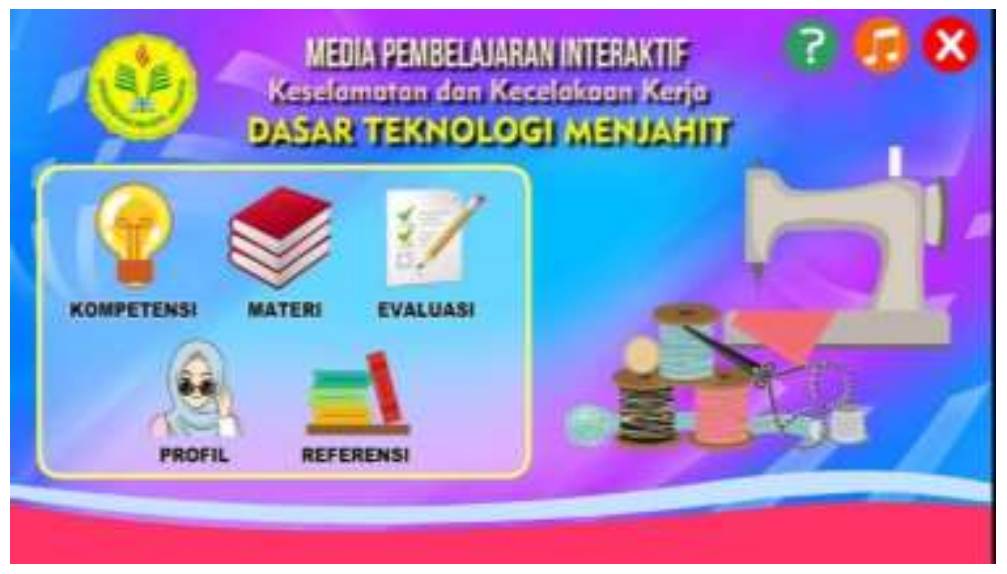

Gambar 2. Menu Utama Media Pembelajaran Interaktif

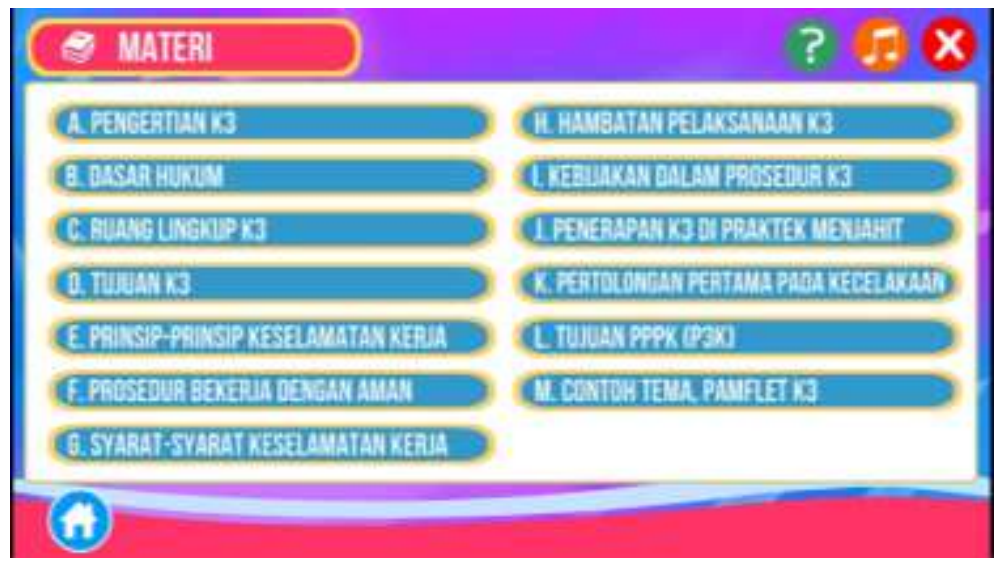

Gambar 3. Materi Media Pembelajaran

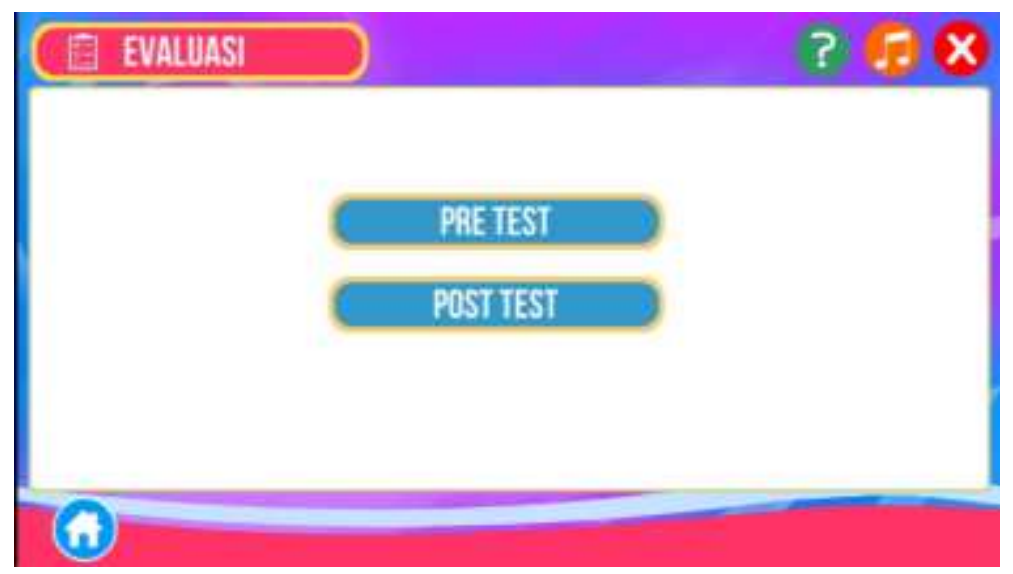

Gambar 4. Evaluasi Media Pembelajaran

Al Qalam: Jurnal Ilmiah Keagamaan dan Kemasyarakatan Vol. 16, No. 1 Januari - Juni 2022 
Christiana Sukmawati, Dewi Suliyanthini, Shinta Doriza : Pengembangan Media Interaktif Teknologi Menjahit Sebagai Scaffolding Penguasaan Pengetahuan Konseptual

Sebelum dilakukan uji coba, produk media divalidasi oleh dua orang ahli materi dan dua orang ahli media. Hasil validasi menunjukkan bahwa produk yang dikembangkan layak untuk untuk digunakan berdasarkan hasil persentase dari ahli materi sebesar $91.67 \%$ dan ahli media sebesar $90 \%$. Para ahli memberikan saran yaitu supaya aplikasi bisa diinstal pada perangkat lain selain perangkat mobile dengan sistem operasi Android, adanya penambahan link video pembelajaran pada materi dan mengganti audio yang disesuaikan dengan karakteristik siswa.

Kelayakan media pembelajaran berdasarkan respon dari siswa juga dinyatakan layak dengan persentase $89 \%$ untuk uji coba pada kelompok kecil dan $87 \%$ untuk uji coba pada kelompok besar. Efektivitas penggunaan media interaktif teknologi menjahit dinilai cukup baik, hal tersebut dapat dilihat dari kenaikan rata-rata hasil evaluasi berupa tes. Saat dilakukan pre test dan post tes di uji coba kelompok kecil mengalami peningkatan rata-rata nilai sebesar 17.5 dengan nilai rata-rata pre test 69.5 dan post test 87, sedangkan saat di uji coba di kelompok besar juga ada peningkatan nilai rata-rata yang cukup baik sebesar 14 dengan nilai rata-rata pre test 71 dan rata-rata post test 85

\section{KESIMPULAN DAN SARAN}

Hasil pengembangan berupa media pembelajaran interaktif mata pelajaran teknologi menjahit. Pengembangan media pembelajaran dilakukan berdasarkan model pengembangan Borg and Gall yang sudah dimodifikasi menjadi 9 tahap perkembangan. Produk telah divalidasi oleh ahli materi, ahli media, dan pengguna. Hasil penelitian menunjukkan bahwa produk yang dikembangkan layak untuk untuk digunakan berdasarkan hasil persentase dari ahli materi sebesar $91.67 \%$ dan ahli media sebesar $90 \%$. Kelayakan media pembelajaran berdasarkan respon dari siswa juga dinyatakan layak dengan persentase $89 \%$ untuk uji coba pada kelompok kecil dan $87 \%$ untuk uji coba pada kelompok besar. Efektivitas penggunaan media interaktif teknologi menjahit dinilai cukup baik, hal tersebut dapat dilihat dari kenaikan rata-rata hasil evaluasi berupa tes. Saat dilakukan pre test dan post tes di uji coba kelompok kecil mengalami peningkatan rata-rata nilai sebesar 17.5 dengan nilai rata-rata pre test 69.5 dan post test 87, sedangkan saat di uji coba di kelompok besar juga ada peningkatan nilai rata-rata yang cukup baik sebesar 14 dengan nilai rata-rata pre test 71 dan ratarata post test 85

Penerapan media pembelajaran dengan media interaktif untuk siswa kelas X Tata Busana pada mata pelajaran teknologi menjahit akan berdampak positif untuk proses kegiatan belajar mengajar. Oleh kerena itu, pendidik harus lebih kreatif dan inovatif dalam mengembangan media pembelajaran yang digunakan dalam proses pembelajaran sehingga hasil belajar siswa akan meningkat. Untuk perkembangan ke depannya dapat dilakukan penelitian lanjutan pada mata pelajaran lain dan siswa di tingkat kelas yang berbeda

\section{DAFTAR PUSTAKA}

Alake, Ese Monica, and Olatubosun Ogunseemi, 'Effects of Scaffolding Strategy on Learners' Academic Achievement in Integrated Science at The Junior Secondary School Level', European Scientific Journal, 9.19 (2013), 149-55 <https://doi.org/http://dx.doi.org/10.19044/esj.2013.v9n19p\%25p>

Arsyad, Azhar, Media Pembelajaran (Jakarta: PT. Raja Grafindo Persada, 2013)

Al Qalam: Jurnal Ilmiah Keagamaan dan Kemasyarakatan Vol. 16, No. 1 Januari - Juni 2022 
Christiana Sukmawati, Dewi Suliyanthini, Shinta Doriza : Pengembangan Media Interaktif Teknologi Menjahit Sebagai Scaffolding Penguasaan Pengetahuan Konseptual

Dikshit, Jyotsna, Suresh Garg, and Santosh Panda, 'Pedagogic Effectiveness of Print, Interactive Multimedia, and Online Resources: A Case Study of IGNOU', International Journal of Instruction, 6.1 (2013), 195-210 <https://doi.org/10.12973/iji.2016.9115a〉

Emzir, Metodologi Penelitian Pendidikan Kuantitatif Dan Kualitataif (Bandung: Rajagrafindo Persada, 2012)

LEOW, Fui-Theng, and Mai NEO, 'Interactive Multimedia Learning: Innovating Classroom Education in A Malaysian University', Turkish Online Journal of Educational Technology, 13.2 (2014), 99-110

Mulyatiningsih, Endang, Metode Penelitian Terapan Bidang Pendidikan (Bandung: Alfabeta, 2013)

Periangan, Benardo, Perancangan Media Interaktif Belajar Mengenal Angka Bagi Anak Prasekolah (Bandung: Universitas Komputer Indonesia, 2011)

Suhito, 'Menumbuhkan Kemampuan Kognitif Dimensi Konseptual Dalam Perkuliahan Geometri Pada Jurusan Matematika FMIPA Unnes', in Prisma, Prosiding Seminar Nasional Matematika, 2018, I, 464-70

<https://journal.unnes.ac.id/sju/index.php/prisma/article/view/20133>

Wakhidah, Nur, 'Strategi Scaffolding Inspiring-Modeling-Writing-Reporting (IMWR) Dalam Menerapkan Pendekatan Saintifik Untuk Meningkatkan Keterampilan Proses Sains Dan Penguasaan Konsep' (Universitas Negeri Surabaya, 2016)

$<$ http://digilib.uinsby.ac.id/15748/>

Al Qalam: Jurnal Ilmiah Keagamaan dan Kemasyarakatan Vol. 16, No. 1 Januari - Juni 2022 